Supplement of Geosci. Model Dev. Discuss., 8, 6707-6756, 2015

http://www.geosci-model-dev-discuss.net/8/6707/2015/

doi:10.5194/gmdd-8-6707-2015-supplement

(C) Author(s) 2015. CC Attribution 3.0 License.

(c) (i)

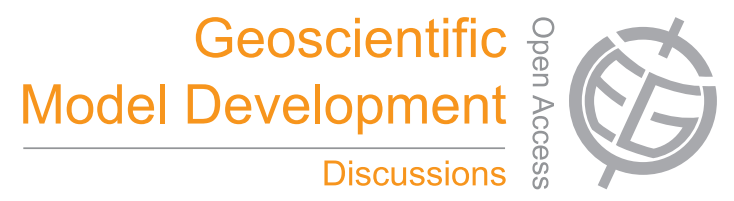

Supplement of

\title{
Decadal evaluation of regional climate, air quality, and their interactions using WRF/Chem Version 3.6.1
}

K. Yahya et al.

Correspondence to: Y. Zhang (yang_zhang@ncsu.edu)

The copyright of individual parts of the supplement might differ from the CC-BY 3.0 licence. 


\section{Mapping of RCP Emissions to CB05 species}

Table S1 summarizes the mapping of species from RCP emissions to CB05 species for input into the model. The explanation for the mapping process can be found in the main text. 
Table S1. CB05 emissions species for WRF/Chem, their associated long names, their availability in regards to the RCP emissions dataset, and the lumped RCP group species.

\begin{tabular}{|c|c|c|c|}
\hline $\begin{array}{l}\text { CB05 Species } \\
\text { WRF/Chem }\end{array}$ & Species Long name & $\begin{array}{l}\text { RCP } \\
\text { Species } \\
\text { Available }\end{array}$ & RCP Group \\
\hline E_ALD2 & Acetaldehyde & Group & Other Alkanals \\
\hline E_ALDX & Higher Aldehydes & Group & Hexanes and Higher Alkanes \\
\hline E_BENZENE & Benzene & Yes & \\
\hline E_CH4 & Methane & Yes & \\
\hline E_CL2 & Chlorine & No & \\
\hline E_CO & Carbon Monoxide & Yes & \\
\hline $\begin{array}{l}\text { E_ECI, E_ECJ, } \\
\text { E_ECC }\end{array}$ & $\begin{array}{l}\text { Elemental Carbon - Nuclei, Accumulation, } \\
\text { Coarse Modes }\end{array}$ & $\begin{array}{l}\text { No, Group, } \\
\text { No }\end{array}$ & Black Carbon \\
\hline E_ETH & Ethene & Yes & \\
\hline E_ETHA & Ethane & Yes & \\
\hline E_ETOH & Ethanol & Group & Alcohols \\
\hline E_FORM & Formaldehyde & Yes & \\
\hline E_HCL & Hydrogen Chloride & No & \\
\hline E_HONO & Nitrous Acid & No & \\
\hline E_IOLE & Internal Olefin Carbon Bond & Group & Other Alkenes and Alkynes \\
\hline E_ISOP & Isoprene & No & \\
\hline E_MEOH & Methanol & Group & Alcohols \\
\hline E_NH3 & Ammonia & Yes & \\
\hline E_NH4I, E_NH4J & Ammonium - Nuclei, Accumulation Modes & No & \\
\hline E_NO & Nitrogen Oxides & Yes & \\
\hline E_NO2 & Nitrogen Dioxide & No & \\
\hline $\begin{array}{l}\text { E_NO3I, E_NO3J, } \\
\text { E_NO3C }\end{array}$ & $\begin{array}{l}\text { Nitrate - Nuclei, Accumulation, Coarse } \\
\text { Modes }\end{array}$ & No & \\
\hline E_OLE & Terminal Olefin Carbon Bond & Group & Other Alkenes and Alkynes \\
\hline $\begin{array}{l}\text { E_ORGI, E_ORGJ, } \\
\text { E_ORGC }\end{array}$ & $\begin{array}{l}\text { Organics - Nuclei, Accumulation, Coarse } \\
\text { Modes }\end{array}$ & $\begin{array}{l}\text { No, Group, } \\
\text { No }\end{array}$ & Organic Carbon \\
\hline E_PAR & Paraffin Carbon Bond & No & \\
\hline E_PM10 & Unspeciated $\mathrm{PM}_{10}$ & No & \\
\hline E_PM25 & Unspeciated $\mathrm{PM}_{2.5}$ & No & \\
\hline E_PM25I, E_PM25J & $\begin{array}{l}\text { Unspeciated } \mathrm{PM}_{2.5}-\text { Nuclei, Accumulation } \\
\text { Modes }\end{array}$ & No, No & \\
\hline E_PSULF & Sulfuric Acid & No & \\
\hline E_SO2 & Sulfur Dioxide & Yes & \\
\hline $\begin{array}{l}\text { E_SO4I, E_SO4J, } \\
\text { E_SO4C }\end{array}$ & $\begin{array}{l}\text { Sulfate - Nuclei, Accumulation, Coarse } \\
\text { Modes }\end{array}$ & No, No, No & \\
\hline E_TERP & Terpene & No & \\
\hline E_TOL & Toluene & Yes & \\
\hline E_XYL & Xylene & Yes & \\
\hline
\end{tabular}




\section{Observational Datasets for Model Evaluation and Operational Evaluation}

Table S2 summarizes the observational databases and the variables evaluated in this work. For evaluation of chemical concentrations and meteorological variables, the surface networks include the National Climatic Data Center (NCDC) Quality Controlled Local Climatological Data (QCLCD), Clean Air Status and Trends Network (CASTNET), the Aerometric Information Retrieval System (AIRS) - Air Quality System (AQS), the Interagency Monitoring of Protected Visual Environments (IMPROVE), the Speciated Trends Network (STN), the Southeastern Aerosol Research and Characterization (SEARCH), and the National Atmospheric Deposition Network (NADP). Several aerosol-cloud-radiation variables are also evaluated against satellite retrievals including the Clouds and the Earth’s Radiant Energy System (CERES) and the Moderate Resolution Imaging Spectroradiometer (MODIS).

NCDC QCLCD data contains data over 700 U.S. locations from July 1996 to December 2004, and over 1600 locations from 2005 onwards (http://www.ncdc.noaa.gov/data-access/land-basedstation-data/land-based-datasets/quality-controlled-local-climatological-data-qclcd). CASTNET observations have been collected in a range of rural environments, from desert to agricultural locations, and from flat to complex terrains (http://java.epa.gov/castnet/epa_jsp/sites.jsp). It contains measurement data for meteorological variables and chemical concentrations. AIRSAQS is the U.S. EPA's repository for ambient air quality data from over 5000 active monitors (http://www.epa.gov/ttn/airs/airsaqs/). While IMPROVE observations have been collected in protected visual environments, i.e., in National Parks and Wilderness Areas (http://vista.cira.colostate.edu/improve/), STN sites are located in a range of locations from urban 
to rural areas (http://www.epa.gov/ttnamti1/specgen.html). Both networks contain data for $\mathrm{PM}_{2.5}$ and major $\mathrm{PM}_{2.5}$ species. NADP contains precipitation data from rain gauges.

Table S2. Observational datasets and variables evaluated in this study.

\begin{tabular}{|c|c|c|c|}
\hline \multicolumn{4}{|c|}{ Gases and PM Species } \\
\hline $\begin{array}{l}\text { Observational } \\
\text { database }\end{array}$ & Variables evaluated & $\begin{array}{l}\text { Sampling } \\
\text { Frequency }\end{array}$ & Number of Sites \\
\hline CASTNET & Max 1-hr and 8-hr $\mathrm{O}_{3}$ & Daily for $\mathrm{O}_{3}$ & $\sim 90$ \\
\hline AIRS-AQS & $\mathrm{O}_{3}$ & Hourly & $\sim 1150$ \\
\hline IMPROVE & $\begin{array}{l}\mathrm{PM}_{2.5}, \mathrm{SO}_{4}{ }^{2-}, \mathrm{NO}_{3}{ }^{-}, \\
\mathrm{NH}_{4}^{+}, \mathrm{EC}, \mathrm{OC}\end{array}$ & $\begin{array}{l}\text { 24-hour data. Data } \\
\text { availability once } \\
\text { every } 3 \text { days }\end{array}$ & $\sim 160$ \\
\hline STN & $\begin{array}{l}\mathrm{PM}_{2.5}, \mathrm{SO}_{4}{ }^{2-}, \mathrm{NO}_{3}^{-}, \\
\mathrm{NH}_{4}^{+}, \mathrm{EC}, \mathrm{TC}\end{array}$ & $\begin{array}{l}\text { 24-hour data. Data } \\
\text { availability once } \\
\text { every } 3 \text { days }\end{array}$ & $\sim 200$ \\
\hline \multicolumn{4}{|l|}{ Meteorology } \\
\hline $\begin{array}{l}\text { Observational } \\
\text { Database }\end{array}$ & Variables evaluated & Temporal Resolution & Spatial Resolution \\
\hline NCDC QCLCD & $\begin{array}{l}\text { T2, RH, } \\
\text { WS10,WD10 }\end{array}$ & Hourly & $\begin{array}{l}\sim 700 \text { before } 2005 \\
\sim 1600 \text { after } 2005\end{array}$ \\
\hline NADP & Precipitation & Weekly & 255 \\
\hline \multicolumn{4}{|c|}{ Radiation and other Aerosol/Cloud variables } \\
\hline $\begin{array}{l}\text { Observational } \\
\text { Database/ Satellite }\end{array}$ & Variables evaluated & Temporal Resolution & $\begin{array}{l}\text { Number of sites/ } \\
\text { Spatial Resolution }\end{array}$ \\
\hline CERES & SWDOWN & Monthly & $1^{0} \times 1^{0}$ \\
\hline MODIS & $\begin{array}{l}\text { AOD, CF, COT, } \\
\text { CWP, QVAPOR, } \\
\text { CCN }\end{array}$ & Monthly & $1^{0} \times 1^{0}$ \\
\hline $\begin{array}{l}\text { MODIS derived } \\
\text { based on Bennartz } \\
(2007)\end{array}$ & CDNC & Monthly & $1^{0} \times 1^{0}$ \\
\hline
\end{tabular}




\section{List of Acronyms}

Table S3. List of Acronyms used in the paper

\begin{tabular}{|c|c|}
\hline Acronym & Full Name \\
\hline AER/AFWA & $\begin{array}{l}\text { The Atmospheric and Environmental Research Inc. and Air Force } \\
\text { Weather Agency scheme }\end{array}$ \\
\hline AERONET & The Aerosol Robotic Network \\
\hline AIRS-AQS & the Aerometric Information Retrieval System-Air Quality System \\
\hline $\mathrm{AOD}$ & Aerosol optical depth \\
\hline BCs & Boundary Conditions \\
\hline CAM5 & The Community Atmosphere Model version 5 \\
\hline CASTNET & The Clean Air Status and Trends Network \\
\hline CALIOP & The Cloud-Aerosol Lidar with Orthogonal Polarization \\
\hline CB05 & The Carbon Bond 2005 \\
\hline CCN & Cloud condensation nuclei \\
\hline CDNC & Cloud droplet number concentration \\
\hline CERES & The Clouds and the Earth's Radiant Energy System \\
\hline CESM & The Community Earth System Model \\
\hline CESM_NCSU & CESM/CAM5 developed at the North Carolina State University \\
\hline CLDFRA & Cloud fraction \\
\hline CMAQ & The Community Multiscale Air Quality Model \\
\hline CMIP5 & The Coupled Model Intercomparison Project Phase 5 \\
\hline CONUS & Continental U.S. \\
\hline COT & Cloud optical thickness \\
\hline CRU & Climatic Research Unit \\
\hline CWP & Cloud water path \\
\hline EC & Elemental carbon \\
\hline GCMs & General circulation models \\
\hline GCTMs & Global chemical transport models \\
\hline GLW & Longwave radiation \\
\hline GSW & Net shortwave radiation \\
\hline ICs & Initial Conditions \\
\hline IMPROVE & The Interagency Monitoring of Protected Visual Environments \\
\hline IOA & Index of Agreement \\
\hline IPCC & The Intergovernmental Panel on Climate Change \\
\hline JFD & January, February and December \\
\hline JJA & June, July, and August \\
\hline LSM & Land Surface Model \\
\hline LST & local standard time \\
\hline LWCF & Longwave cloud forcing \\
\hline MADE/VBS & The Modal for Aerosol Dynamics in Europe / Volatility Basis Set \\
\hline MAM & March, April, and May \\
\hline MAN & The Maritime Aerosol Network \\
\hline MB & Mean bias \\
\hline MEGAN2 & The Model of Emissions of Gases and Aerosols from Nature version 2 \\
\hline
\end{tabular}




\begin{tabular}{|c|c|}
\hline MODIS & The Moderate Resolution Imaging Spectroradiometer \\
\hline NADP & The National Atmospheric Deposition Network \\
\hline NARR & The North American Regional Reanalyses \\
\hline NCDC & The National Climatic Data Center \\
\hline NCEP & The National Centers for Environmental Prediction \\
\hline NCEP FNL & The NCEP Final Reanalyses \\
\hline NEI & The National Emission Inventory \\
\hline $\mathrm{NH}_{4}^{+}$ & Ammonium \\
\hline NMB & Normalized mean bias \\
\hline NME & Normalized mean error \\
\hline $\mathrm{NO}_{3}{ }^{-}$ & Nitrate \\
\hline NO & Nitric oxide \\
\hline $\mathrm{NO}_{2}$ & Nitrogen dioxide \\
\hline $\mathrm{NO}_{\mathrm{x}}$ & Nitrogen oxide \\
\hline NOAH & $\begin{array}{l}\text { The National Center for Environmental Prediction, Oregon State } \\
\text { University, Air Force and Hydrologic Research Lab }\end{array}$ \\
\hline $\mathrm{O}_{3}$ & Ozone \\
\hline $\mathrm{OA}$ & Organic aerosol \\
\hline OC & Organic carbon \\
\hline OMI & The Ozone Monitoring Instrument \\
\hline $\mathrm{PM}_{2.5}$ and $\mathrm{PM}_{10}$ & Particulate matter with diameter less than and equal to 2.5 and $10 \mu \mathrm{m}$ \\
\hline POA & Primary organic aerosol \\
\hline PRECIS & Providing Regional Climates for Impacts Studies \\
\hline $\mathrm{R}$ & Correlation coefficient \\
\hline RCMs & Regional climate models \\
\hline RCP & The Representative Concentration Pathway \\
\hline RH2 & Relative humidity at 2-m \\
\hline RRTMG & The Rapid and accurate Radiative Transfer Model for GCM \\
\hline SEARCH & The Southeastern Aerosol Research and Characterization \\
\hline SMOKE & The Sparse Matrix Operator Kernel Emissions model \\
\hline SOA & Secondary organic aerosol \\
\hline $\mathrm{SO}_{2}$ & Sulfur dioxide \\
\hline $\mathrm{SO}_{4}^{2-}$ & Sulfate \\
\hline SON & September, October, and November \\
\hline STN & The Speciated Trends Network \\
\hline SWCF & Shortwave cloud forcing \\
\hline SWDOWN & Downward shortwave radiation \\
\hline $\mathrm{T} 2$ & Temperature at 2-m \\
\hline TC & Total carbon, = EC + OC \\
\hline WD10 & Wind direction at $10-\mathrm{m}$ \\
\hline WRF & Weather Research and Forecasting model \\
\hline WRF/Chem & The Weather Research and Forecasting model with Chemistry \\
\hline WS10 & Wind speed at $10-\mathrm{m}$ \\
\hline
\end{tabular}




\section{References}

Bennartz, R. (2007), Global assessment of marine boundary layer cloud droplet number concentration from satellite, J. Geophys. Res., 112, D02201, doi:10.1029/2006JD007547. 